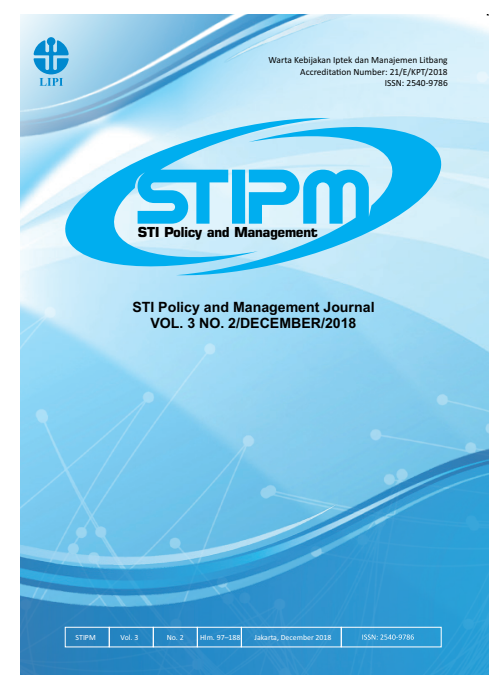

Journal of STI Policy and Management

Publication details, including instructions for authors and subscription information: http://www.stipmjournal.org/

\title{
Technology-Based Startup: A Formula to Become Sustainable Company in Indonesia a Case Study from UAVINDO Nusantara
}

\section{Uruqul Nadhif Dzakiy}

Institut Teknologi Bandung, Indonesia

Version of record first published: 15 December 2018

To cite this article: Dzakiy, U.N. (2018). Technology-Based Startup: A Formula to Become Sustainable Company in Indonesia a Case Study from UAVINDO Nusantara. Journal of STI Policy and Management, 3(2), 137-144 To link to this article: http://dx.doi.org/10.14203/STIPM.2017.152

ISSN 2540-9786 (Print); ISSN 2502-5996 (online)

Accreditation Number: 21/E/KPT/2018

Full terms and conditions of use: https://creativecommons.org/licenses/by-nc-sa/4.0/

You are free to:

- Share : copy and redistribute the material in any medium or format

- Adapt : remix, transform, and build upon the material

- The licensor cannot revoke these freedoms as long as you follow the license terms.

Under the following terms: Attribution - You must give appropriate credit, provide a link to the license, and indicate if changes were made. You may do so in any reasonable manner, but not in any way that suggests the licensor endorses you or your use.

$\$$ NonCommercial - You may not use the material for commercial purposes.

(3) ShareAlike - If you remix, transform, or build upon the material, you must distribute your contributions under the same license as the original.

No additional restrictions - You may not apply legal terms or technological measures that legally restrict others from doing anything the license permits.

Notices:

- You do not have to comply with the license for elements of the material in the public domain or where your use is permitted by an applicable exception or limitation.

- No warranties are given. The license may not give you all of the permissions necessary for your intended use. For example, other rights such as publicity, privacy, or moral rights may limit how you use the material.

- If you copy the dataset merely to extract the uncopyrightable data elements would not need permission to do so. However, if you republish the full dataset or using the copyrightable data layers require a permission from PAPPIPTEK-LIPI. 


\title{
JOURNAL OF SCIENCE, TECHNOLOGY, AND INNOVATION POLICY AND MANAGEMENT (STIPM JOURNAL), Volume 03, Number 02, December 2018
}

\author{
FOREWORD by EDITOR-in-CHIEF
}

We are very pleased to inform the readers that Journal of Science, Technology, \& Innovation Policy and Management (STIPM Journal) Vol. 3, No. 2, December 2018 is now ready for public reading and views. STIPM Journal is an online research journal, managed by the Center for Science and Technology Development Studies, Indonesian Institute of Sciences (PAPPIPTEK-LIPI).

This journal in fact provides scientific information needed mostly by research scholars. As a peer reviewed journal, STIPM provides free public access to all articles. Two issues, namely scientific review on variables and dimensions of national innovation capability, as well as research findings on development and adoption of science, technology, and innovation policy and management from Japan and Indonesia, are presented.

The first article "Internal Innovation Capacity and External Lingkages in Firms of ASEAN Economies Focusing on Endogeneity" is composed by Masaru OGAWA et al. This research article examines the role of internal innovation capacity, which includes technological level, organizational learning, and human resources on innovation. The second research article entitled "Drivers of Innovation without Formal R\&D: Selected Cases of Indonesian Firms". This article is presented by Erman AMINULLAH et al. The objective of this research study is to obtain a deep understanding about "why and how" firms engaging in innovation without formal $\mathrm{R} \& \mathrm{D}$, through deep analysis of three cases of firms in machinery and food processing sectors.

Uruqul Nadhif DZAKIY presents an article entitled "Technology-based Start-up: A Formula to become Sustainable Company in Indonesia, Lessons-learned from UAVINDO Nusantara". UAVINDO is a sample of technology-based company in Indonesia which has the characteristics of sustainable company. The fourth article entitled "Development Strategy of National Microsatellite Industry: Case Study of Indonesia", is presented by Chusnul Tri JUDIANTO et al. By applying SWOT and Quantitative Strategic Planning Matrix (QSPM) methods, this research identifies and analyzes the alternative strategy from external and internal factors and selects the appropriate and precise strategy for developing the microsatellite industry.

Hadi KARDOYO et al. present an article entitled "Knowledge Accumulation-based Entrepreneurship in the Creative Industry: A Case Study of Woodwork Firms in Indonesia." This article describes the activities of knowledge-entrepreneurship in four wood craft firms, namely Radio Magno, Stranough Guitar Technologi, Secco Guitar, and Matoa Watch, and also shows some lessons from Knowledge Intensive Entrepreneur (KIE). The last article composed by Ahmad Dading GUNADI et al. presents a "Scientifc Review on National Capability Variables and Dimensions." This paper analyses the dimensions and variables of National Innovation Capability through a system approach that includes three sub-systems, namely Input, Process, and Output. 
After indexing by Google Scholar, ISJD and IPI, STIPM Journal is now indexed with DOAJ, BASE, and OCLC World Cat. This has made the journal's dissemination broader. We would like to express our immense gratitude to our international editorial board members, reviewers and authors for their contribution to this issue. We hope this publication will prove useful for readers and could contribute to the enhancement of science, technology and innovation innitiatives. We expect that STIPM will always provide a higher scientific platform for authors and readers, with a comprehensive overview of the most recent STI Policy and Management research and development at the national, regional dan international levels. Finally, wishing you a HAPPY NEW YEAR 2019. May your New Year be filled with great achievements, good health, peace, happines, and joy.

Jakarta, December 2018

Editor-In-Chief 



\section{JOURNAL OF STI POLICY AND MANAGEMENT}

Volume 3, Number 2, December 2018

\section{LIST OF CONTENTS}

Internal Innovation Capacity and External Linkages in FIRMS of ASEAN Economies Focusing on Endogeneity

Masaru Ogawa, Yasuhi Ueki, Hiroki Idota, Teruyuki Bunno, and Masatsugu Tsuji

Drivers of Innovation Without Formal R\&D: Selected cases of Indonesian firms

Erman Aminullah, Trina Fizzanty, Qinan M.B. Soesanto.

Technology-Based Startup: A Formula to Become Sustainable Company in Indonesia a Case Study from UAVINDO Nusantara

Uruqul Nadhif Dzakiy

Development Strategy of National Microsatellite Industry: Case Study of Indonesia

Chusnul Tri Judianto, Harianto, and Agus Maulana

Knowledge Accumulation-Based Entrepreneurship (KABE) in the Creative Industry: A Case Study of Woodwork Firms in Indonesia

Hadi Kardoyo, Setiowiji Handoyo, and Anugerah Yuka Asmara $161-173$

National Innovation Capability Variables and Dimensions

Ahmad Dading Gunadi, Yandra Arkeman, Rizal Syarief Siaiful Nazli, Teguh Rahardjo, and Aulijati Wachjudiningsih. 


\title{
Technology-Based Startup: A Formula to Become Sustainable Company in Indonesia (a Case Study from UAVINDO Nusantara)
}

\author{
Uruqul Nadhif Dzakiy a,* \\ ${ }^{a}$ Institut Teknologi Bandung, Indonesia \\ uruqul@itb.ac.id
}

\begin{tabular}{lll}
\hline ARTICLE INFO & ABSTRACT \\
\cline { 1 - 1 } $\begin{array}{l}\text { Article History: } \\
\text { Received : 15 November 2018 }\end{array}$ & $\begin{array}{l}\text { Technology-based startups are not numerous in Indonesia and have } \\
\text { faced problems restricting their growth. Not many of them are } \\
\text { Revised : 01 December 2018 }\end{array}$ & $\begin{array}{l}\text { sustainable. UAVINDO Nusantara is an exception. The company, } \\
\text { concerned with unmanned aerial vehicle (UAV) technology, was }\end{array}$ \\
Accepted : 01 December 2018 & & $\begin{array}{l}\text { founded in 2000 and has survived since. It has passed three periods of } \\
\text { development (building trust, crisis and rising up) before committed }\end{array}$ \\
\hline Keywords: & to be a solution provider company in aeronautics for the military \\
AVINDO Nusantara & market. Its changed capability of organizational management, its \\
Technology-based startup & innovation culture, and ability to become trusted company are \\
Indonesian company & characteristics for the company to become sustainable. Three factors \\
Sustainable company & that shape it like that are leadership of its manager (director), learning \\
culture inside the company, and ability to maintain its network.
\end{tabular}

\section{INTRODUCTION}

Doing business for technology-based companies is a problem in Indonesia. Not many enterprises are sustainable in creating and marketing products. The reasons are very complicated, including the business ecosystem and government regulation.

The number of companies existing in Indonesia that are technology-based company is small, even though the potential for them is larger than for ordinary business. The question is, how to make them become a main player in the Indonesian economy? A difficult question, but to lay the first stone, it is crucial to give understanding to those enterprises how to survive.

\footnotetext{
* Corresponding Author. Tel: +6285228830783

E-mail: uruqul@itb.ac.id
}

UAVINDO is a local drone industry that has survived for more than ten years. When first founded in 2000, this company faced several crises that nearly led to its closing down. Now, it is a leading drone company for military technology in Indonesia. Learning from the development path of a sustainable company like UAVINDO is interesting. The lessons learned provides the survival factors that can be evidence to create policies to support development of sustainable technology-based companies.

Two research questions rise. First, how is the journey taken by UAVINDO Nusantara that made it a successful sustainable company in Indonesia? Second, what are the factors that made UAVINDO a successful sustainable company in Indonesia? 


\section{LITERATURE REVIEW}

\section{A. Technology-Based Startup}

Technology-based company consists of hardware, software, and service. In this context, drone company is a part of a hardware company. It creates products for sale. Salamzadeh and Kesim (2015) explained that path of the startup company consists of three parts: bootstrapping, seed and creation stage.

Bootstrapping stage. This is a very early stage that entrepreneur himself/herself initiates a set of activities to turn his/her idea into a profitable business. However, he/she considers a higher risk or even uncertainty level, continues working on the new venture idea, builds a team, uses personal funds, and asks family members and friends for their investment in the idea.

Seed stage. This stage is characterized by team work, prototype development, entry into market, valuation of the venture, seeking for support mechanism such as accelerators and incubators, and average investments to grow the startup.

Creation stage. This stage occurs when the company sells its products, enters into market, and hires first employees. At the end of this stage, organization/firm is formed and corporate finance is considered as the main choice for financing the firm. Venture capitals could facilitate the creation stage, by funding the venture.

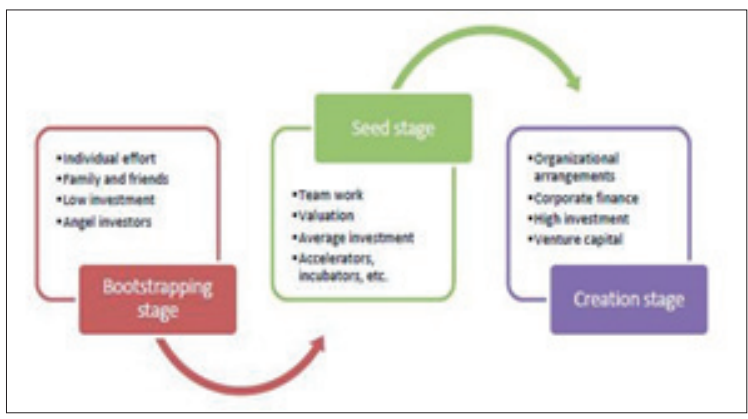

Source: Salamzadeh and Kesim (2015)

Figure 1. Lifecycle of Startups

\section{B. Sustainable Company}

Based on Eccles, Perkin, and Serafeim (2012), sustainable companies are different from traditional ones in three ways; effective at engaging with external stakeholders and employees, having cultures based on innovation and trust, and having a track record of implementing large-scale change. There are two stages that make a company sustainable.

Stage one: Reframing the Company's Identity. Reframing the company's identity is composed of two elements: leadership commitment and external engagement. To gain commitment, leaders must engage with groups outside of their organizational boundaries, such as investors and NGOs that represent civil society. Effective external engagement cannot happen without strong commitment from the leadership team. By engaging the two elements, a company can begin to fashion a new identity as a sustainable enterprise.

Leadership Commitment. When leadership commitment drives the process, it usually comes from the personal resolution of a CEO to create a more sustainable company. In general, top-level executives have the ability to create an enterprise-wide vision and the clout to see that it is realized. Without this commitment, becoming a sustainable company is a "nonstarter".

External Engagement. Companies that thrive with a sustainable strategy realize the importance of reaching beyond their own internal boundaries to a variety of external stakeholders. Sustainable companies learn from the outside and collaborate with other companies and organizations to advance their goals.

Stage two: Codifying the New Identity. This stage involves building internal support for the new identity through employee engagement and mechanisms for execution, two elements that are closely intertwined. Of course, leadership commitment and external engagement do not end, they are embedded in and drive the codification of the company's new identity. In essence, the first stage continues into the second stage, and once both stages are in process, they reinforce each other and create a culture supportive of sustainability.

Employee engagement. Employee engagement is defined as actions a company takes to secure the interest and attention of employees in their sustainability efforts. Engaged employees 
are emotionally connected to their work and to their workplace. As a result, they tend to be more productive and more willing to engage in discretionary efforts to achieve company goals.

Mechanisms for Executions. The CEO often initiates the codification of the new behavior by driving the change through organizationwide mechanisms and by promoting employee engagement. The study found that some of the most pronounced differences between sustainable and traditional companies are the presence of mechanisms for execution and how they are used.

\section{Supportive Organizational Culture}

Over time, the codification of a sustainable company's new identity will reinforce, or even establish, a culture based on change capabilities, trust and innovation. Leadership commitment and external engagement are necessary for transformational change. Employee engagement fosters trust and innovation, and mechanisms for execution ensure that change happens as innovations diffuse throughout the organization. In turn, a culture supportive of sustainability will increase the effectiveness of leadership commitment, external engagement, employee engagement, and mechanism for execution.

Change capabilities. Companies with developed capabilities for transformational and incremental change may be able to move more quickly; those lacking the cultural capabilities with inevitably proceed in a more halting fashion and are more likely to need help or fail.

Innovation. Sustainable companies use a variety of approaches to incorporate continuous learning into their cultures. Innovation is most likely to occur in organizations where lateral and vertical communication is enabled and people with different frames of reference can come together to share ideas. Rather than suppressing conflict, sustainable companies tend to encourage the airing of diverse points of view. They appreciate that, when handled well, enterprise-wide conversations tend to create understanding across the organization. In addition to leading to synergy and innovation, these conversations also build trust.
Trust. Creating a sustainable company requires trust on the part of every employee. Without trust, employees are reluctant to take the risks that innovation requires, and they are reluctant to engage. Trust is the difference between hearing, listening and believing. It permits people to act in new ways that truly contribute to the development of a sustainable company.

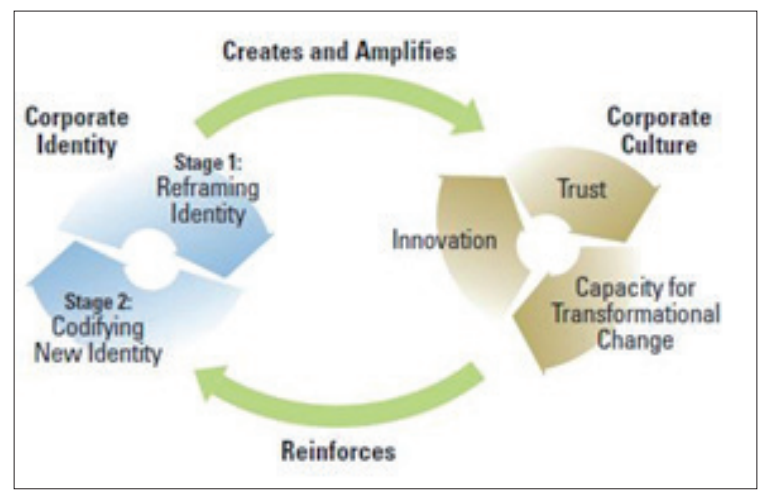

Source: Eccles et al. (2012)

Figure 2. The Role of Corporate Culture in Sustainability

\section{METHODOLOGY}

This is a qualitative research. There were two kind of data used in this research. The first was primary data collected through interviews with related actors such as company founders, engineers, technicians, and directors. The second was secondary data from related journal articles, books, and documents. Last, data analysis relied on pattern-matching techniques (Yin, 2009), iteratively examining the correspondence between data and theory (Sushandoyo \& Magnusson, 2014).

\section{RESULTS AND DISCUSSION}

\section{A. Results}

UAVINDO Nusantara is the first unmaned aerial vehicle (UAV) company in Indonesia (Jupriyanto, 2007). This company used the first UAV prototype developed by Institut Teknologi Bandung (ITB) in 1994 named Sky-Spy-20 (SS-20) as early promotion. It was founded in 2000.

In the beginning, the company had an office in the aerodynamics laboratory ITB in the Aerodynamics, Design, and Business Centre 
(ADBC). Its main concern was research projects in aeronautics. Then, three years later it transformed to be legal company by name PT UAVINDO Nusantara. As founder, Mr. DS holds 75 percent of share versus 25 percent for company's employees.

In the early stage, UAVINDO consisted of 12 engineers who were students of the Department of Aeronautics Engineering ITB. Only two of them were student of Geodetics Engineering ITB. By this team, UAVINDO successfully had a first project that mapped Segara Anakan (Lake of Anakan) in Cilacap, Central Java.

Building Trust. UAVINDO was built after Indonesian Aerospace Industry (IPTN) had crisis in 1997. This company was founded by DS, a former engineer for IPTN. He was an aerodynamist, graduated from Delft University of Technology (TU Delft) that became Head of Wing Division for N2130, second IPTN's aircraft generation after N250.

By his experience in IPTN, DS was challenged to build a technology-based company related to his field. He was already in UAV, but not produced aircraft like what IPTN successfully did. However, by prototype SS-20, he started to go further in this industry. Mostly he did all process in industrial cycles by practice (not by design). He was well trained in engineering but not in running a company. However, first he founded $\mathrm{ADBC}$, a body concerned with research in aeronautics engineering.

Even UAVINDO promoted UAV in many events like exhibition in BPPT Jakarta and also delivering letters containing the company's portfolio. Unfortunately, there was no order for UAV. In the end, one project was obtained; mapping of Segara Anakan (Lake of Anakan) in Cilacap, Central Java. This project was obtained after the exhibition closed. The wind-tunnel project was earned not long after that. It happened after Djoko asked his friends who taught in a Malaysian university to spread the brochure of UAVINDO. From this, UAVINDO got two wind-tunnel projects, one from Universiti Putra Malaysia (UPM) and others from Kolej University Teknology Tun Husin Onn (KUITTHO).
Another way of getting clients was after a meeting between group of aeronautics students from ITB, a director of technology and innovation Department of Defense (Dirtekin Dephan), BS. They discussed UAV technology. BS said that he looked for small-medium-company of defense technology to be supervised through his division. The students then mentioned the DS name with his work of UAV in UAVINDO. Not long after that, there was intense communication between Dephan and UAVINDO.

After signing an agreement with Dephan, UAVINDO produce six UAV SS-5 that were a scaled-down version of SS-20. In this project, UAVINDO made a joint venture with WES, a private company. There were also two new companies created as a consequence of this agreement: WA to handle manufacturing process of SS-5 and WG to do other projects related to aerial mapping. From this venture, share majority was owned by ND as the director of WES (60 percent) and the rest was owned by DS as the director of UAVINDO (40 percent).

Man Behind the Company. The development of UAVINDO had been strongly influenced by DS. He was a former aerodynamics engineer at IPTN. When IPTN developed N2130, he was a Head of Wing Division. Before, he was appointed as an IPTN engineer; he had bachelor degree of Aeronautics Engineering at ITB and Doctoral Degree at TU Delft, The Netherlands.

When the financial crisis happened in 1997 and impacted the project, DS chose to resign and came back to ITB as a full time lecturer. Then, this campus became a trial and error for him to run a company. In the beginning, he founded Aerodynamics, Business, and Design Centre (ADBC) in 1999 to do aeronautics engineering research projects. Three years later, a professional company named UAVINDO was founded with him as its director.

Those were problems arising in the period in running UAVINDO. A key issue was how to get projects. DS as the founder marketed the company's products in many ways; formally and informally. Formally, he joined exhibitions like in BPPT Jakarta in 1998 with using SS-20 as a product prototype and sending letters to 
several government ministries during that time. Informally, by "word of mouth" he spoke to his friends who worked as a lecturer in Malaysia. As a result, the company got a mapping project at Segara Anakan in Cilacap and not long after that, the company got project for two universities in Malaysia to build wind tunnel.

Not easy for Mr. DS to run a company while being a lecturer. Before the company existed, he asked Dean of Faculty of Mechanical Engineering and Aeronautics (FTMD) in that time for permission. He was willing to stay in position as assistant professor because of his "industrialist" choice. He committed to run UAV company totally.

Crisis. There were two crisis raised. It was a failed flight test at Atang Sanjaya airport in 2002. In that time, UAVINDO demonstrated a UAV type SS-20 that was ordered by Ministry of Defence (Kemhan). Unfortunately, the UAV failed in flight test because of the lack of communication. There was no control that led the UAV to crush not long after it took off. This accident caused frustration in team members but DS, as director, convinced Kemhan, as a client, that UAVINDO could overcome the problem as soon as possible. Several months later, a new product was successfully flown.

However, a bigger crisis happened in 2003 when WES, a venture partner of UAVINDO in running project UAV SS-5 from Kemhan, denied the agreement. Initially, this company committed to be investor, but in the end it only provided the backup cost of building products. Therefore, after the project finished, there was no new machine investment. The ownership of two new companies created (by WA and WG) ended. Therefore, team members of UAVINDO in these projects became company's employees, including UAVINDO's Director, DS.

This latter crisis made many UAVINDO's team resign, falling from 12 engineers to only 3 members. Three years after the crisis in 2003, UAVINDO had only one project from LAPAN to rehabilitate a transonic tunnel. This made its team members break temporary in earning monthly salary. Including its director, the employees looked for another job to fulfill their daily needs.

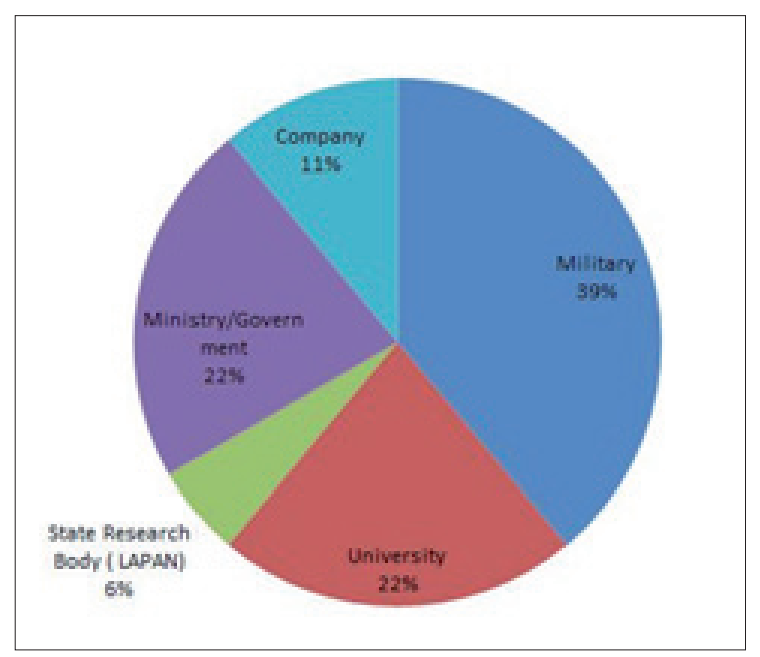

Source: Dzakiy (2018)

Figure 3. Clients of UAVINDO for 2000-2018

After doing several projects together, UAVINDO and Kemhan's cooperation become much stronger. After 2006, UAVINDO got bigger projects every years. Two were about defence: first from Indonesia Army (TNI AD) asking to build surveillance UAV and second from Department of Defense (Dephan) asking to build combat UAV. The majority of clients were from the military (39\%) and ministries/government (22\%) during the period from 2000 until 2018.

Rising Up. Getting a large market gave opportunity for UAVINDO to grow. By the time, its director hired new teams. A new director, RB - former DS's student—gave the company a fresh perspective.

He convinced that UAVINDO would not only produce UAV, but also created other products like wing tunnel, skydiving tunnel, survey car, and flight simulator. UAVINDO is a solution-provider company in aeronautics.

The company also implements merit system in its business process. Flexibility in working positions is always being encouraged. Exchanging positions from one project to another is usual. Earned salary follows degree of influence in projects. This new direction makes no discrimination between new hire and the old one. The company's organization was made as lean as possible. In idle condition, the directors consist of three persons, engineer 10 persons, technicians 5 persons, and administration 2 persons. If there is a project that needs more people to solve, the company will recruit freelancers. 


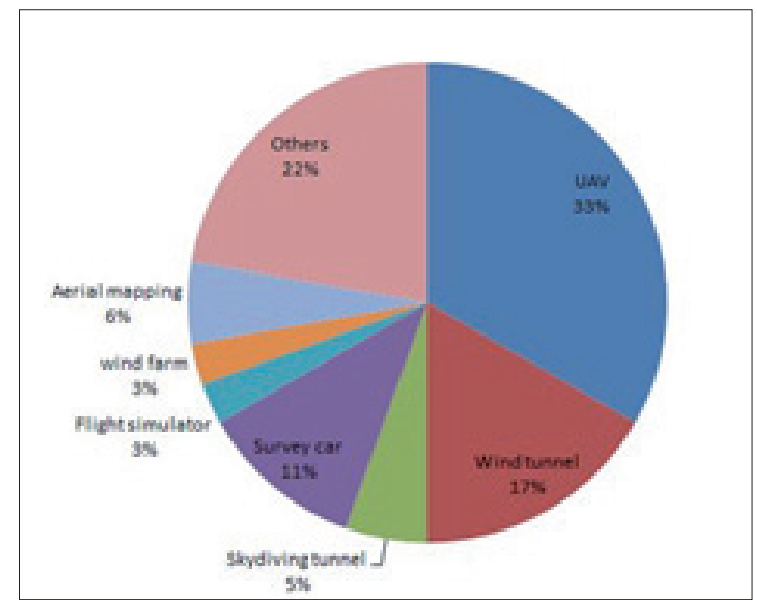

Source: Dzakiy (2018)

Figure 4. Products of UAVINDO for 2000-2018

\section{B. Discussion}

UAVINDO Nusantara has characteristics of sustainable company like what Eccles et al. (2012) explained.

Change capabilities. Even the company for the first time planned to make UAV as its main product, the company also opened to other opportunities based on market in that time. This flexibility strengthened its identity as a solutionprovider company in aeronautics.

Another point is when the crisis happened in 2003, the company tended to be more careful to make joint-venture with another company. This accident also changed its management arrangements. Now, its work achievement is designed based on degree of influence in projects with the depth staff which involved in projects becomes a main parameter to determine the employee's salary.

Innovation. Products developed by UAV are varying. In the beginning, the company developed type of fixed wing that can bring $5 \mathrm{~kg}$ load (SS-5) and fly for 4 hours, now the new one can bring $40 \mathrm{~kg}$ load (CR-40) and fly for 12 hours. Other types are multirotor, backpack, target drone, and high speed drone. Beside products, innovation is its business process.

Being Trusted. Now, the company has a license from Department of Defence to produce defence equipment like skydiving tunnel, one and only in Indonesia. Other products like UAV for surveillance and wind tunnel have license too. This certificate makes UAVINDO more competitive to grab market share.

The question is then, what are the factors that make UAVINDO competitive?

Leadership. UAVINDO has a strong vision since 2000. Its founder took responsibility in company financing, looked for potential clients, and committed to continually develop products. When the flight test of SS-20 in front of Indonesian Army (TNI) leaders crashed in 2002, the team was depressed. The director never blamed the team but encouraged them to rise. "Mr. DS (the director) always encourages us, he is aware with our limited experience, he covers up all", said SP, one of the first employees in UAVINDO.

Now, the company control is not on the hand of DS, but on his first employee, RB. RB reaffirms this company as a solution provider in aeronautics. Its work environment is designed as flexible as possible because work performance depends on degree of influence in projects. There is no difference between senior and junior employee. They have the same chance to reach the top. RB also can keep knowledge of company that can be looked from its massive development of the product like UAV. He is able to keep the company to maintain its core technology although some employees are in and out from the company.

Learning culture. One thing that differs a startup company from established company is the small team membership. Another side, this number becomes company's advantage because one employee can learn with another employee. In one time, a team member of a wind-tunnel project can switch to another project like UAV. Change of focus in short time happens because team members can learn quickly from each other. In every project, there is a team leader who takes full responsibility for a successful project. Another case, after crash of SS-20 in 2002, it did not take long time for the company to create new products and be successful. This was a sign that learning culture has become a part of this company.

Ability to maintain network. Military is the biggest company's client with 39 percent 
(Figure 3). This is because the company can take strong relationship with military. Military became a client before the company was officially founded. In that time, Ministry of Defense (Kemhan) collaborated with aeronautics laboratory ITB to develop surveillance UAV, SS-20. After UAVINDO was built, military keep collaborating in developing another product like UAV SS-5, a scale-down version of SS-20. The collaboration continues not only to develop UAV, but also to develop skydiving tunnel and to procure defense equipment. License of product from Kemhan for surveillance UAV, skydiving, and wind tunnel for UAVINDO was a sign that the company can create trust to military sectors.

\section{Theoretical Contribution}

This research limits organizational scope and refers to what Eccles et al. (2012) defined. In the previous research of Bocken (2015) and De Lange (2017), sustainable entrepreneurship (including startup) consists of three dimensions: economic health (economy), social equity (people), and environmental resilience (planet). However, this research only discussed the economic aspect. Further research should identify two other aspects of sustainability or not to use the term "sustainability" to eliminate ambiguity with the environment.

The interesting aspect of this study is its case study that is from a country that does not have an economic ecosystem for hardware startup like UAVINDO.

Attention from Government to support the establishment of a large company to this sector is relatively small. Even with this condition, a hardware startup company (especially in aeronautics products) like UAVINDO could still survive. Therefore, this case is worth exploring.

From this research, we get three factors that influence organization sustainability of the startup; leadership of its manager (director), learning culture inside the company, and the ability to maintain network with clients. This finding may enrich the technology-based company studies in a third world country. In future research, those factors should be checked for its validity and relevancy to similar type company in Indonesia.

\section{CONCLUSION}

There are four points that can be triggered from this research.

1) UAVINDO's journey consists of three parts: building trust, crisis management, and rising up. This company commits to become a solution provider company in aeronautics that has majority of its clients in the military market.

2) UAVINDO is characterized as a sustainable company because of its change capability of organizational management, innovation, and taking license for its products to build market trust.

3) Three factors that made UAVINDO a sustainable company: leadership of its manager (director), its learning culture inside the company, and the ability for the company to maintain its network.

4) This research contributes to theory on the organizational aspect of technology-based startup company in developing country. Future research should check validity and relevancy those factors to similar type company in Indonesia.

\section{REFERENCES}

Bocken, N. M. P. (2015). Sustainable venture capital-catalyst for sustainable start-up success? Journal of Cleaner Production, 108(Part A), 647-658.

De Lange, D. E. (2017). Start-up sustainability: An insurmountable cost or a life-giving investment? Journal of Cleaner Production, 156, 838-854.

Dzakiy, U. N. (2018). Startup teknologi: Lintasan yang harus ditempuh, menarik pelajaran dari PT UAVINDO Nusantara. Bandung: ITB Press.

Dzakiy, Uruqul, N. \& Yuliar, S. (2017). Dari IPTN menuju PT UAVINDO Nusantara: Sebuah pergeseran triple helix inovasi dan implikasinya pada kebijakan IPTEKIN. In Prosiding Forum IPTEKIN PAPPIPTEK LIPI VII 2017, 340. Jakarta: Pappiptek-LIPI.

Eccles, R. G., Perkin, K. M., \& Serafeim, G. (2012). How to become a sustainable company. MIT Sloan Management Review, 53(4), 43-50. 
Jupriyanto. (2007). A roadmap of Indonesian UAVS development. (Thesis). Defense Studies, Development Studies Program, School of Architecture, Planning, and Policy Development ITB.

Salamzadeh, A. \& Kesim, H. K. (2015). Startup company: Life cycle and challenges. Retrieved from http://www.academia.edu/13846089/ Startup_Companies_Life_Cycle_and_Challenges.
Sushandoyo \& Magnusson. (2014). Strategic niche management from a business perspective: Taking cleaner vehicle technologies from prototype to series production. Journal of Cleaner Production, 74, 17-26.

Yin, R. K. (2009). Case study research: Design and methods ( $4^{\text {th }}$ Ed.). Thousand Oaks, CA: Sage. 